\title{
A successful institutional policy of quality postgraduates at the UABC
}

\author{
Huber-Bernal, Gerardo ${ }^{a}$; Moctezuma-Hernández, Patricia ${ }^{a}$ and Ocegueda- \\ Hernández, Juan Manuel ${ }^{\mathrm{a}}$ \\ ${ }^{a}$ School of Economics and International Relations, Autonomus University of Baja \\ California (UABC), Calzada Universidad 14418, Tijuana, B.C., 22390, Mexico.
}

\begin{abstract}
This paper analyzes the postgraduate institutional policy in the Autonomous University of Baja California (UABC) implemented since 2003. Aligning the educational model of the UABC with the parameters of the National Program of Postgraduate Quality (PNPC in spanish), the results-based budget and the matrix of indicators of the logical margin and articulating them to the maximum qualifications of national recognition granted to the full time professors at higher education institutions, its results are explained by the continuity of the policy and organizational capacity of the institutional management, which has resulted in the improvement of the quality and coverage in the postgraduate level, achieving from 2013 that 100\% of its programs are recognized for their quality and the first institution of the 34 state public universities existing in the country to reach it sustainably. This policy implemented by the UABC also should be reflected in the satisfaction of graduates and employers, in the contribution in the generation of knowledge through journals high impact factor, the degree of linkage with the productive sector measured through collaboration agreements and management of resources for public-private-social projects, which will be topics for future research.
\end{abstract}

Keywords: Higher quality education, higher education policy; postgraduate; public policies evaluation. 


\section{Introduction}

In the last 20 years, an increasingly interconnected world environment and a progressive specialization and technological development in almost all areas of knowledge, have been transformed the economic and socio-cultural sphere. This has generated a process of intense global competition among almost all countries seeking better living conditions and welfare for their inhabitants. Higher education institutions through postgraduate as a means of transformation and knowledge management, undertake the challenge of transforming, diversifying and expanding their educational offer to improve their competitiveness and answers graduates to the needs and demands of the labor market (Mungaray, 1994). The creation of postgraduate programs includes high-level human resources training to address national problems and priorities through science, technology and innovation in strategic areas that detonate economic development. On the other hand, "the quality of a postgraduate degree [...] does not depend on the type of institution that offers it, the target population it attends or the educational function for which it forms, but on a curriculum design with a good level of internal congruence with attainable objectives and an operation totally coherent with its main purpose" (Moreno, 2002). This quality is measured by its relevance, social impact and scientific-technical relevance. The challenge currently faced by graduate education programs in Mexico is to scale the professional and academic level of postgraduate education programs that allow them to raise their level of quality and relevance, which in turn are sustainable and sustainable in the long term In response to changes in the academic sector and that respond to the needs of the labor market driven by economic sectors and contribute to knowledge and its application in solving local, regional and international problems (ANUIES, 2000; Moreno, 2002; Rubio, 2006).

\section{Conceptual aspects on the evaluation of public policies}

In the field of public policy evaluation, there is a whole discussion as to the best analytical framework for locating and evaluating the results, since the analysis based on assumptions based on empirical evidence prevails, but without any analytical framework that supports them. De Vries and Álvarez (2005) argue that in the policy analysis "an analytical framework is necessary that considers a wide range of factors that affect the public policy and allow hypotheses that are tried in the reality that they try to describe and to understand". To do this, it is convenient to consider the analyzes on the political structure to evaluate results and impacts, the using of techniques of measurement of integral analysis that complement hard data (quantitative information) with surveys that provide information of a subjective nature (qualitative information). In the field of the evaluation of higher education policies, there is a wide discussion about the characterization, trends, implementation, administration, organization, reforms and institutional arrangements within 
educational systems and subsystems (Dawkins, 1987; Mungaray and López, 1996; Barrow et al, 2003; Roth, 2007). From these analyzes, some of them have broken out in lines of action to promote the development of higher education at a global level such as those proposed by UNESCO (1995). At the national level, these same elements of analysis are present, linking them to the different historical moments of national politics (ANUIES, 2000, Luengo, 2003; OECD, 2004 and Rubio, 2006). With the introduction of the ResultsBased Budgeting in Mexico since 2008, public expenditure planning is sought with a focus on achieving results using the Logical Framework Approach. The UABC has implemented this methodology in its planning process to facilitate the monitoring and evaluation of its budgetary programs linked to the results of the policies and strategies of the institutional development plans 2011-2015 and 2015-2019.

\section{Methodology}

The hypothesis of the present work is that the improvement of the quality and coverage in the postgraduate level is the result of a focused policy and of the organizational capacity of the continuous institutional management in the last fourteen years within the framework of the UABC educational model (2006). The main focus are the full-time professors (PTC). Through its activities, studies or projects in disciplinary and multidisciplinary subjects, product of basic or applied research. This allows them to deepen their field of knowledge of the disciplinary areas of educational programs as an integral part of the teaching-learning process. By sharing similar topics and common academic objectives, these teachers formalize Lines of Generation and Knowledge Application, conforming themselves to Researchers Groups certified by the Ministry of Public Education of Mexico. Once they consolidate their capacities, lines and research work, they acquire the PTC Certified whose recognition is also done through an evaluation process by the Ministry of Public Education and / or enter the National System of Researchers (NSR) through National Council of Science and Technology of Mexico (CONACYT in spanish), contributing in an important way to the consolidation, strengthening and maintenance of the quality of educational programs. The accreditation and recognition of the quality of the postgraduate programs guarantee the quality of the training of the human resources in the institution and answer the solution of national and local problems. 


\section{4. $U A B C$ postgraduate indicators}

\subsection{Full time professors (PTC) and PTC Certified}

The intensification of the globalization process and the knowledge society have touched the universities and all its members in the world. The UABC has assumed the vision about the important role of the researcher teacher in relation to the challenges they face in the years to come. The evolution of the PTC Certified in the UABC, has grown significantly since 2002, at an average annual rate of $13.6 \%$, passing form $27 \%$ out of total PTC to $69 \%$ en 2016, placed in the second best national effort among autonomus public institutions in Mexico. This new profile is undoubtedly a new seed capital for the formation and consolidation of the academic bodies of the institution, whose recognition is done through an evaluation process by the Ministry of Public Education of Mexico, with teaching, generation or innovative application of knowledge, mentoring, academic management and linkage in a balanced manner.

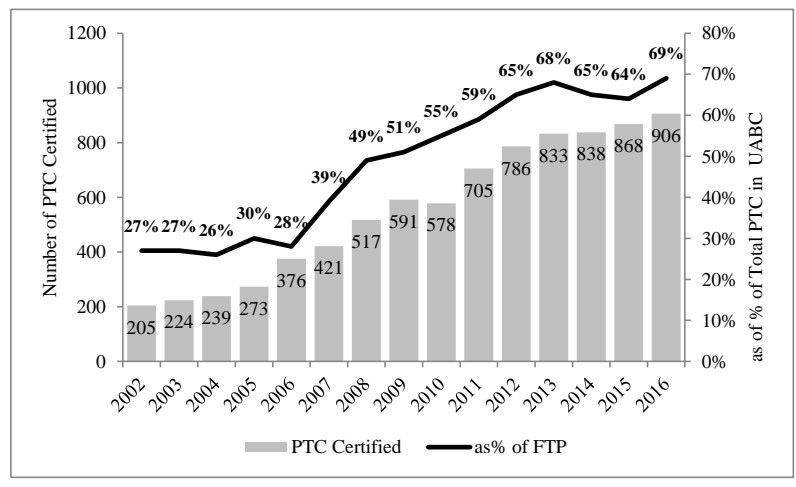

Figure 1. UABC PTC Certified 2002-2016.

Source: own elaboration.

\subsection{National System of Researchers (NSR)}

In 1984, Ministry of Public Education of Mexico created the NSR "with the aim of increasing international competitiveness in research, linking and solving national problems, as well as recognizing activities related to scientific and technological research with quality, training Specialized human resources, high performance and efficiency through the provision of economic incentives" (DOF, 1984). Based on this, the UABC has been continuously promoting an annual increase in the number of academics who belong to the NSR since 1999, by promoting research and teaching as a synergy for the benefit of teachers and students in general. At the end of 2016 (Figure 2) the UABC has 333 
academics in the NSR, of which 86 are Candidates, 196 Level I, 40 Level II and 11Level III. By levels and with information available since 2010, there is a transition between levels, which indicates that research in the institution generates quality in its contributions and projects and that resources and human capital are being formed at a high level. This has allowed the UABC to be the educational institution of Baja California where the largest human capital with scientific and technological capacity is concentrated, from $24 \%$ of the institution's SNIs in 2002 to $46.5 \%$ in 2016 (Figure 3).

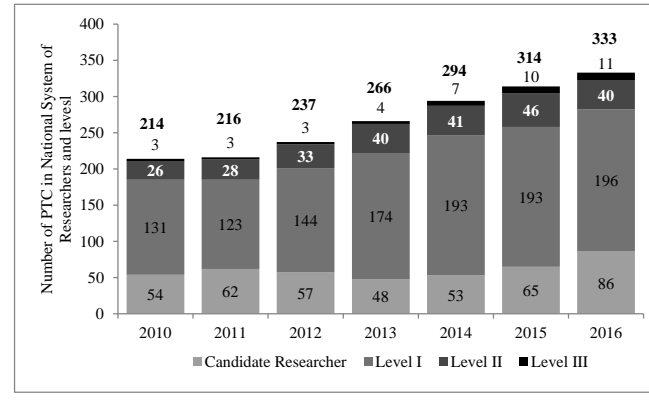

Figure 2.NSRs at UABC 2010-2016.

Source: own elaboration.

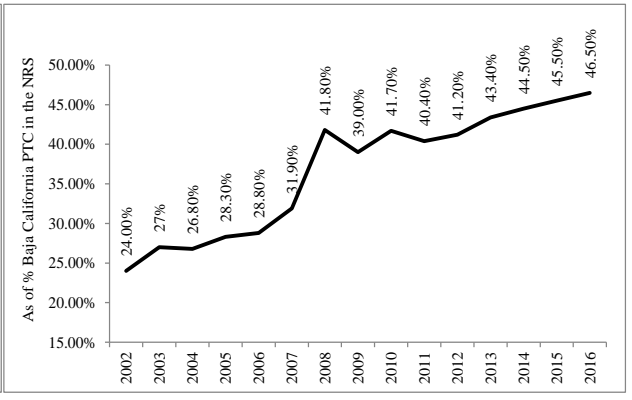

Figure 3.UABC NSRs / Baja California NSR 2002-2016.

Source: own elaboration.

\subsection{Researchers Groups Certified}

The Researcher Groups Certified of the UABC have been consolidated from the previous experience of their members research and collective work for their relationship with teaching in graduate programs. This has allowed to achieve an optimal performance of its students and the training of competitive professionals whose capacities can be located in the labor market. As can be seen in Figure 4, from 2002 to 2006, the figure of Groups is sown in the UABC and from 2007 to 2010 its consolidation is priorized. As of 2011, institutional policy follows a two-pronged strategy: to continue with the consolidation of the Groups and to enable the creation of new ones as a response to the growth PTC Certified, as well as to the need for teachers to explore new lines of research and establishing collaborative links through national and international networks. 


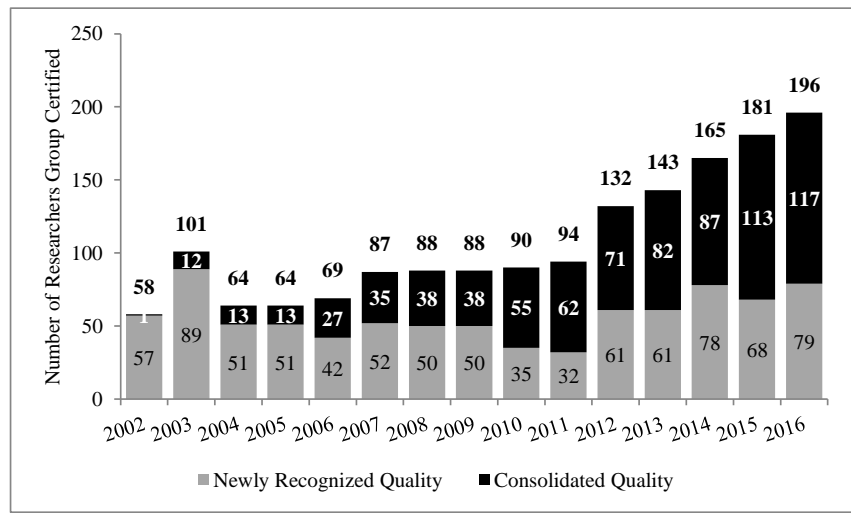

Figure 4. Researcher Groups Certified at UABC 2002-2016.Source: own elaboration.

\subsection{UABC postgraduates programs incorporated to the PNPC}

Since 1991, the Ministry of Public Education and CONACYT have been promoting the public policy of promoting postgraduate qualifications in Mexico through "the recognition of the quality of postgraduate programs offered by higher education institutions and research centers, through rigorous peer review processes, and is awarded to programs that demonstrate they have met the highest standards of quality and relevance" (CONACYT 2015). The quality is observed in the transit of UABC postgraduate programs enrolled in the PNPC at levels in Development and Consolidated between 2010 and 2014. This transit has been possible due to the greater qualification of PTC with graduate level in the NSR and in the improvement of level of the Researchers Group Certified. This has also strengthened academic competencies, investigative skills and resource management within their respective Main Core Academic. As it showns in Figure 5, from the 43 UABC postgraduate programs in the PNPC, 5 are Newly Quality Recognized, 21 Consolidating and 11 Consolidated. Also, 19 of these programs are professionally oriented $(44.2 \%)$ and 24 are research oriented $(55.8 \%)$. With the postgraduate quality assurance policy that is implemented in the institution and with the effort of the university community, the UABC achieves in 2013 that $100 \%$ of its graduate programs are enrolled in the PNPC, becoming the only institution of the 34 state public universities in the country to reach and sustain it. 


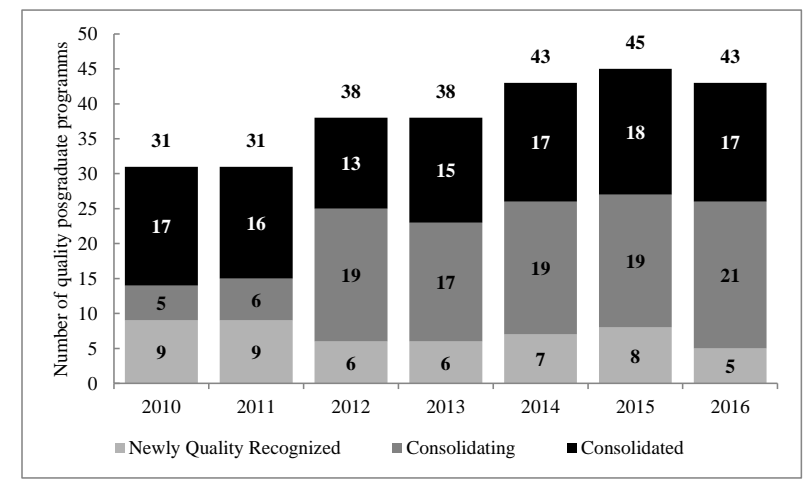

Figure 5. UABC Postgraduates programs in PNPC 2010-2016. Source: own elaboration.

\section{Concluding Remarks}

Achieving the quality of the postgraduate programs required by the scientific and technological community through CONACYT, requires a great effort. At the same time, it represents a great challenge to remain accredited once the acceptance to the PNPC has been achieved, which becomes part of the institutional stress and creativity. That is why $100 \%$ of the 43 postgraduate educational programs offered by the UABC enrolled in the PNPC are addressed as strategic issues, with the aim of raising efficiency and effectiveness levels through continuous improvement, quality and transparency. Although the effort of the country's Higher Education Institutions to increase the quality of its postgraduate courses is evident, there are two outstanding subjects in terms of evaluation and accreditation that guarantee its sustainability and continuous improvement. On the one hand, at the federal level, it is necessary for the State to maintain improvement actions in the evaluation and accreditation processes, but also in the instrumentation and monitoring of the indicators that measure the performance of the postgraduate programs. On the other hand, it is required that at the state level, modifications to the certification and accreditation processes be undertaken in a more rigorous and comprehensive manner, regulating the opening and operation of postgraduate programs in public and private higher education institutions with approved quality criteria with the PNPC. This would allow all market-driven efforts to be addressed with quality and not only with credentialist criteria and economic profitability. For the $\mathrm{UABC}$, the future main challenge is to guarantee the articulation and congruence between our institutional practices, with the criteria of the evaluating and accrediting agencies of the programs, in order to have the same harmony and stay in the competition. The creation of a postgraduate program aims to materialize the professional activities of scientific research, in the training of human resources at the highest level of quality. A key component in the relevance and sustainability of the quality of a postgraduate program, is 
the academic commitment of PTC who make up the Main Core Academic of each program, from the selection of candidates to the follow-up to their insertion in the workforce. This training cycle, coordinated jointly and collegially by all those involved in a quality postgraduate offer, is what holds $100 \%$ of the quality postgraduate in the UABC.

\section{References}

ANUIES (2000). La Educación Superior en el Siglo XXI, las Líneas Estratégicas de Desarrollo, una Propuesta de la ANUIES. Revista de Educación Superior. 13. 1-8. México. Retrieved from :http://publicaciones.anuies.mx/pdfs/revista/Revista113_S5A2ES.pdf

Barrow, C.W., Didou-Aupetit, S. \& Mallea J. (2003). Globalisation, Trade Liberalization, and Higher Education in North America. The Emergence of a New Market under NAFTA? Higher Education Dynamics. Kluwer Academic Publishers. 1-255.

CONACYT (2015). Marco de Referencia para la Evaluación y Seguimiento de Programas de Posgrado Presenciales. Retrieved from: http://www.conacyt.mx/index.php/becas-yposgrados/programa-nacional-de-posgrados-de-calidad/convocatorias-avisos-yresultados/convocatorias-cerradas-pnpc/9005-marco-de-referencia-modalidadescolarizada/file.

Dawkins J.S. (1987). Higher Education. A Policy Discussion Paper. Asutralia: Australian Government Publishing Service.

De Vries, W. \& Álvarez, G. (2005). Acerca de las Políticas, la Política y otras Complicaciones en la Educación Superior Mexicana. Revista de la Educación Superior, 134, Vol. XXXIV (2), abril-junio de 2005, 81-105.

DOF (1984), "Creación de Sistema Nacional de Investigadores", Diario Oficial de la Federación, 26 de julio de 1984. Retrieved from: http://dof.gob.mx/nota_detalle.php?codigo=4680072\&fecha=26/07/1984

Luengo, E. (2003). Tendencias de la Educación Superior en México: una Lectura desde la Perspectiva de la Complejidad. Seminario sobre Reformas de la Educación Superior en América Latina y el Caribe, Bogotá, ASCUN - IESALC / UNESCO, 3-65

Moctezuma, P., Huber, G. \& Valdés, S. (2015). 100\% de Posgrado de Calidad en la UABC. Políticas, Logros y Retos para la Competitividad Institucional. Impala Comunicación Gráfica. Agosto de 2015. Mexicali.

Moreno, B. (2002). Innovación en los Posgrados en Educación ¿Sólo un Caso Particular de lo Posible?. Revista de la Educación Superior. 31(124). 73-84.

Mungaray, A. \& López, R. (1996). Introduction to the Latin American Challenges and perspective in the nineties. Higher Education Policy. vol. 9 (1). 3-9.

Mungaray, A., (1994). Reforma Curricular y Organización Alternativa para Mejorar la Eficiencia del Posgrado Mexicano. Revista de la Educción Superior. Número 90. Volumen 23. abril-junio $1994 . \quad$ Retrieved from: http://publicaciones.anuies.mx/pdfs/revista/Revista90_S2A3ES.pdf 
OCDE (2004). Revisión Nacional de Investigación y Desarrollo Educativo. Reporte de los examinadores sobre México. Revista Mexicana de Investigación Educativa. Abr-Jun 2001. Vol. 9. Num 21. 515-550.

Rubio, J. (coordinador) (2006). La Política Educativa y la Educación Superior en México. 1995-2006: un Balance. Fondo de Cultura Económica, 1era. Edición. México.

Roth, A. (2007). Enfoques y Teorías para el Análisis de las Políticas Públicas, Cambio de la Acción Pública y Transformaciones del Estado. en: J.I Cuervo y otros (eds). Ensayos sobre Políticas Públicas. Universidad Externado de Colombia. Bogotá. 29-63.

UNESCO (1995). Documento de política para el cambio y el desarrollo en la educación superior. UNESCO, ED-94/WS/30. Paris, 3-54.

UABC (2006). Modelo Educativo de la Universidad Autónoma de Baja California. Cuadernos de Planeación y Desarrollo Institucional. Mayo de 2006. Mexicali. 